\title{
HATE CRIMES DI INDONESIA DALAM PERSPEKTIF PERBANDINGAN HUKUM
}

\author{
Widati Wulandari \\ email: widati_w@yahoo.com
}

\begin{abstract}
This article discusses the deficiency of the Indonesian criminal law with regard to the criminalization of hate crimes. Taking into consideration the fact that Indonesia faces a high incidence of social conflict due to rising intolerance and discrimination targeting minority groups. The combination of (racial-ethnic-religious) discrimination and hatred against minority groups in most cases results in various forms of common crimes which generally is known as hate crimes. Using a comparative law method, by and between Indonesian criminal law and the criminal law of other countries experiencing hate crimes, the author highlights options for eradicating hate crimes. One important finding is the tendency of a number of countries to perceive hatred or prejudice which motivate the perpetrator of hate crimes as aggravating factor and not to as as separate substantive offence.
\end{abstract}

Keywords:

hate crimes, hate, prejudice, criminal law

\begin{abstract}
Abstrak
Tulisan ini akan menelaah kurangnya pengaturan hate crimes dalam hukum pidana di Indonesia. Padahal sebagai Negara dengan masyarakat majemuk, Indonesia menghadapi tantangan tingginya angka konflik sosial yang berlatar belakang intoleransi dan perlakuan diskriminatif terhadap kelompok minoritas (ras, etnis, agama). Tidak jarang sikap diskriminatif yang tumpang tindih dengan kebencian pada kelompok minoritas terwujud ke dalam beragam bentuk kejahatan yang lebih dikenal dengan istilah hate crimes. Dengan menggunakan metoda perbandingan hukum, antara hukum pidana Indonesia dengan hukum pidana negara-negara lain yang mengalami hate crimes ditelaah pilihan-pilihan yang terbuka untuk menanggulangi hate crimes. Satu temuan terpenting ialah adanya kecenderungan (dengan alasan pertimbangan tertentu) untuk memandang kebencian yang melatarbelakangi dilakukannya kejahatan (motif) sebagai unsur pemberatan pidana dan bukan sebagai tindak pidana yang berdiri sendiri.
\end{abstract}

Kata-kata kunci: hate crimes, kebencian, prejudice, hukum pidana.

\section{Pendahuluan}

Upaya mempertahankan kedamaian kehidupan dalam keberagaman masyarakat merupakan masalah penting bagi Indonesia. Upaya ini mendapat tantangan serius dari berbagai konflik sosial yang terjadi antar kelompokkelompok masyarakat yang cenderung membedakan diri terutama berdasarkan suku, etnisitas, dan agama. Perlakuan diskriminatif dan sikap intoleran yang diwujudkan dalam berbagai bentuk kekerasan terhadap kelompok berbeda, 
terutama kelompok minoritas, belakangan ini kerap terjadi dalam masyarakat di berbagai wilayah di Indonesia.

Menurut catatan Kepolisian Republik Indonesia (Polri), peristiwa-peristiwa intoleransi di Indonesia meningkat pada 2016. ${ }^{1}$ Tercatat sejumlah peristiwa (baik dengan maupun tanpa kekerasan) yang terjadi akibat adanya prejudice atau sikap bias masyarakat terhadap kelompok tertentu. Kebencian yang diglorifikasi oleh kelompok-kelompok intoleran selanjutnya terwujud dalam perlakuan diskriminatif, seperti: peristiwa pengusiran serta pembakaran rumah masyarakat bekas anggota Gerakan Fajar Nusantara (Gafatar) di Kabupaten Mempwah, Kalimantan Barat pada Januari 2016 yang dianggap sesat dan terafiliasi dengan kelompok ISIS; ${ }^{2}$ Pengusiran Jemaat Ahmadiyah di Bangka oleh Bupati Bangka, Sekda Bangka, Dandim Bangka dan ormas Hizbut Tahir pada awal Februari 2016; ${ }^{3}$ serta peristiwa pembubaran paksa KKR Natal Di Gedung Sasana Budaya Ganesa Bandung yang dipandang sebagai 'ajang pemurtadan' oleh dua ormas Islam yakni Pembela Ahlus Sunnah (PAS) dan Dewan Dakwah Islam (DDI) dengan menggunakan alasan tidak adanya izin untuk menyelenggarakan ibadah di ruang publik. 4

Ditengarai pula bahwa dalam sejumlah kasus collective violence yang terjadi dibiarkan (pembiaran) bahkan disponsori oleh Negara. Terlepas dari ada/tidaknya keterlibatan Negara (baik secara aktif atau pembiaran), dari sejumlah kasus yang diuraikan di atas dapat dicermati adanya satu kesamaan, yakni motif atau latar belakang 'kebencian' serta 'prasangka' (prejudice) atau sikap bias yang dipelihara melalui proses stereotyping terhadap kelompok yang

1 Ahmad Zulfikar Fazli, “25 Kasus Intoleran Terjadi di Indonesia Sepanjang 2016”, metrotvnews, 5 Januari 2017, <http://news.metrotvnews.com/hukum/8N0YX4wb-25-kasus-intoleran-terjadidi-indonesia-sepanjang-2016> [10/01/2017]

2 Heyder Affan dan Christine Franciska, "Pengusiran 1,000 eks anggota Gafatar merupakan Pelanggaran,” BBC Indonesia, 21 Januari 2016

<http://www.bbc.com/indonesia/berita_indonesia/2016/01/160120_indonesia_pengusiran_ga fatar> [10/01/2017]

3 "Kronologi Pengusiran Jemaat Ahmadiyah diBangka", TEMPO.CO, 9 Februari 2016, <https://m.tempo.co/read/news/2016/02/09/058743223/ini-kronologi-pengusiran-jemaatahmadiyah-di-bangka> [10/01/2017]

4 Isyana Artharini, "Alasan Pembubaran Acara Natal di Bandung Mengada-Ada”, BBC Indonesia, 8 Desember 2016 <http://www.bbc.com/indonesia/indonesia-38233417> [10/01/2017] 
dianggap berbeda. Dimaksud dengan stereotyping adalah melanggengkan pandangan negatif terhadap kelompok yang berbeda atau orang-orang dari kelompok yang berbeda sekadar berdasarkan 'pengetahuan' tidak utuh atau tidak lengkap, serta penuh kecurigaan dan purbasangka (bias atau prejudice).

Sebagian konflik sosial tersebut berujung pada sejumlah tindak kekerasan yang dilandasi kebencian atau prejudice dan ditujukan terhadap anggota kelompok-kelompok masyarakat tertentu. Kelompok ini adalah kelompok yang karena ciri-ciri tertentu (suku, ras, agama atau kriteria lain) dipandang berbeda dari, dan umumnya, karena adanya perbedaan itu, dianggap sebagai ancaman oleh anggota kelompok dominan (atau kelompok yang berkuasa) atau kelompok lainnya. Korban dalam peristiwa ini merupakan bagian atau anggota dari kelompok yang dibenci. Dalam kasus-kasus tersebut, korban menjadi target kekerasan (apapun bentuknya) semata-mata didasarkan pada keanggotaannya pada kelompok yang dibenci, bukan sebagai individu. Kejahatan-kejahatan seperti ini dikenal dengan istilah hate crimes. Di Indonesia peristiwa-peristiwa di atas tidak mendapat reaksi pidana yang memadai dari Negara, antara lain, karena ketiadaan aturan yang memadai untuk menjerat pelaku kejahatan berlatar belakang "kebencian" dimaksud.

Tulisan ini hendak menelaah kekurangan pengaturan hate crimes dalam hukum pidana di Indonesia dan memberikan rekomendasi dalam rangka perbaikan pengaturan. Dalam rangka tujuan itu, penulis menggunakan metoda perbandingan hukum pidana. Apa yang diperbandingkan adalah bagaimana hukum pidana di sejumlah negara mengatur kejahatan yang dilakukan dengan "latar belakang kebencian." Hasil perbandingan ini selanjutnya dapat digunakan sebagai masukan pertimbangan bagi pengaturan hate crimes dalam hukum pidana Indonesia. Pada bagian awal akan dipaparkan kajian teoretik tentang hate crimes untuk melihat perkaitannya dengan latar belakang kebencian dan prejudice atau sikap bias. Selanjutnya akan dipaparkan perbandingan pengaturan hate crimes di sejumlah Negara untuk menunjukkan persamaan-perbedaannya dan analisis berkaitan dengan ruang lingkup perlindungan serta metoda yang digunakan 
berbagai negara. Pada bagian terakhir diuraikan ulasan rekomendasi pengaturan hate crimes dalam hukum pidana Indonesia yang akan datang (ius constituendum).

\section{Hate Crimes dan Prejudice}

Kasus-kasus kekerasan sebagaimana diilustrasikan di atas dapat dikategorikan sebagai kejahatan yang berlatar belakang kebencian, sikap bias atau prasangka (prejudice) pada kelompok tertentu (yang berbeda) yang umumnya dianggap sebagai ancaman. Istilah hate crimes pada awalnya muncul di dalam sistem hukum Amerika Serikat. Istilah ini kemudian juga berkembang di Eropa dan Inggris. Pada awalnya, dalam sistem hukum yang berlaku di negara-negara tersebut istilah hate crimes merujuk pada perbuatan-perbuatan yang dikualifikasikan sebagai racially aggravated offences. ${ }^{5}$

Meskipun pustaka hukum maupun peraturan perundang-undangan di berbagai Negara mendefinisikan atau mengkategorikan kejahatan yang digambarkan di atas dengan cara yang berbeda-beda, umumnya hate crimes didefinisikan sebagai: ${ }^{6}$

"berbagai jenis kejahatan/perbuatan pidana yang dilakukan terhadap orang/kelompok orang ataupun harta bendanya dengan latar belakang/motif kebencian/prejudice pelaku terhadap korbannya semata-mata karena korban merupakan anggota kelompok (ras, etnis, kebangsaan, keagamaan, difabilitas, orientasi seksual, dsb) tertentu".

Kebencian yang muncul pada seseorang atau sekelompok orang dapat dimanifestasikan dalam berbagai bentuk perbuatan pidana/kejahatan, seperti pembunuhan, penganiayaan, pelecehan-penghinaan, perkosaan, perusakanpenghancuran barang dan sebagainya. Apa yang penting di sini adalah latar belakang atau motif dilakukannya tindak pidana tersebut. Konteks adanya kebencian, dengan demikian, tidak dapat dikesampingkan begitu saja. Peristiwaperistiwa sebagaimana diuraikan di atas bukan merupakan kejahatan yang berdiri sendiri dan terjadi secara spontan. Kejahatan tersebut umumnya merupakan

5 Irene Sagel-Grande, Hate Crime, Comparative Law Annotation, Groningen University, 2006, hlm., 1.

6 James B. Jacobs dan Henry J, The Social Construction of Hate Crime Epidemic, Vol 86 No 2, The Journal of Criminal Law \& Criminology, 1996, hlm., 366. 
puncak dari akar masalah adanya kesenjangan atau perbedaan perkembangan sosial-politik-ekonomi-budaya antar kelompok-kelompok yang membedakan diri. Dengan kata lain, kejahatan (biasa) yang muncul dilatarbelakangi adanya kecurigaan, bahkan kebencian terhadap kelompok yang berbeda, yang terus dipelihara serta diwariskan turun temurun.

Dalam pustaka ilmu hukum di Indonesia, konsep hate crimes belum banyak didiskusikan. Demikian pula dalam hukum positif Indonesia, hate crimes belum diatur secara jelas. Baru beberapa tahun terakhir sejak munculnya UndangUndang Informasi dan Transaksi Elektronik No. 11 Tahun 2008 dan UndangUndang Anti Diskriminasi Ras dan Etnis No. 40 Tahun 2008 di Indonesia, dikenal konsep ujaran kebencian (hate speech). Ujaran kebencian sekalipun kerap mendahului terjadinya hate crimes harus dipandang berbeda dari hate crimes. Dengan cara serupa hate crimes harus dibedakan dari genosida. Perbedaan dan kaitan keduanya dengan hate crimes akan dijelaskan setelah konsep hate crimes dijelaskan di bawah ini.

Berdasarkan pengamatan ringkas di atas dan dengan tujuan memperoleh gambaran utuh tentang hate crimes, maka diperlukan penelusuran literatur tentang hate crimes yang muncul di sejumlah Negara lain. Seperti telah disebutkan di atas, konsep ini pertama kali muncul di Amerika Serikat. Kemunculan konsep hate crimes di Amerika tidak dapat dilepaskan dari sejarah panjang dan situasi sosial politik yang berkembang di negara tersebut, khususnya berkaitan dengan perlakuan diskriminatif yang termanifestasi dalam berbagai bentuk kekerasan, perbudakan dan persekusi (persecution) terhadap kelompok masyarakat tertentu seperti Native American (Indian-Amerika), masyarakat kulit hitam (African-American) dan para imigran baik Hispanic maupun orang-orang Asia. $^{7}$

Sekalipun istilah hate crimes telah digunakan dalam wacana politik dan sosial di Amerika sejak 1985, konsep ini baru muncul sebagai terminologi dalam hukum positif sebagai salah satu jenis kejahatan pada 1990. Istilah hate crimes

\footnotetext{
7 Phyllis B. Gerstenfeld, Hate Crimes, Causes, Controls and Controversies, $3^{\text {rd }}$ ed, Sage Publications, California, 2013, hlm., 11.
} 
muncul dalam Federal Hate Crimes Statistic Act. Undang-Undang ini memberi mandat pada Attorney General's Office untuk mengumpulkan data dan menerbitkan statistik mengenai “crimes motivated by victim's race, religion, ethnicity, or sexual orientation." Perkembangan ini tidak terlepas dari fakta meningkatnya kesadaran masyarakat Amerika akan perlu dan pentingnya mengelola keberagaman dalam kehidupan masyarakat dan perlunya pengaturan relasi yang seimbang antar ras, agama, gender dan orientasi seksual yang berbeda-beda. ${ }^{8}$

Konsep hate crimes juga muncul dalam berbagai pustaka negara-negara lain di luar Amerika seperti Inggris, Kanada, dan Australia. Masyarakat dari negara-negara tersebut, serupa Amerika, adalah masyarakat multikulturalmultietnis. Khususnya di Inggris, konsep hate crimes mulai mendapat perhatian masyarakat dan pemerintah pasca peristiwa pembunuhan berlatarbelakang rasisme terhadap remaja kulit hitam Stephen Lawrence, serta "nailbomb attack" yang berlatarbelakang rasisme dan homophobia pada $1999 .{ }^{9}$

Mengingat kemunculannya dalam masyarakat multikultural-multi etnis (di negara-negara maju), maka tidak mengherankan bahwa hate crimes pada awal mulanya disebut juga sebagai ethnoviolence, yakni kejahatan atau kekerasan yang berlatar belakang perbedaan etnis dan karenanya terkait erat dengan rasisme (kebencian terhadap ras-etnis tertentu).10 Pada awalnya yang teramati adalah kejahatan-kejahatan yang dilatarbelakangi kebencian atau prejudice terhadap kelompok etnis tertentu yang berbeda. Kebencian atau prejudice itu ditujukan terutama pada kelompok masyarakat kulit hitam, Indian, Hispanic, ataupun kelompok minoritas lainnya dalam tatanan masyarakat dominan kulit putih (Anglo-American White People). Keberadaan mereka oleh kelompok mayoritas

\footnotetext{
8 James B. Jacobs and Kimberly Potter, Hate Crimes: Criminal Law \& Identity Politics, Oxford University Press, Oxford, 1998, hlm., 3-4 .

9 Neil Chakraborti and Jon Garland, Hate Crime: Impact, Causes and Responses, Sage Publications, London, 2009, hlm., 2.

${ }^{10}$ Kay Goodall, Conceptualising 'Racism' in Criminal Law, Vol. 33 No 2 June, Legal Studies, 2013, hlm., 215-238
} 
tersebut dinilai mengancam supremasi/dominasi masyarakat kulit putih (white supremacy).

Di samping itu, hate crimes kerap dijelaskan secara singkat sebagai criminal conduct motivated by prejudice. ${ }^{11}$ Alasannya adalah karena dalam kejahatankejahatan yang termotivasi prejudice, pelaku melakukan kejahatan atau tindak pidana terhadap korban sebagai akibat adanya atau dipengaruhi sikap bias atau prejudice (kebencian atau purbasangka) mereka terhadap kelompok tertentu, dan korban menjadi target semata-mata karena keanggotaannya dalam kelompok yang dibenci. Sebab itu pula mengapa hate crimes secara umum kerap disebut sebagai kejahatan berlatarbelakang kebencian atau prejudice/sikap bias (prejudice motivated crimes atau bias motivated crimes).

Gerstenfeld, sejalan dengan itu, mendefinisikan hate crimes sebagai criminal act that is motivated, at least in part, by the group affiliation of the victim. ${ }^{12}$ Adanya afiliasi korban terhadap kelompok yang dibenci, dalam hal ini, merupakan elemen esensial. Karena itu hanya kejahatan yang termotivasi oleh kebencian terhadap korban, yang dianggap bagian dari kelompok, yang dapat dikategorikan sebagai hate crimes. Kelompok dimaksud merujuk pada kelompok yang dibedakan atas dasar ras, agama dan etnis tertentu. Dalam perkembangannya, ditambahkan ke dalam kelompok berbeda, kelompok-kelompok masyarakat yang berbeda (atau dibedakan) berdasarkan orientasi seksual, gender, difabel, usia, dan kategori lainnya. ${ }^{13}$ Beranjak dari itu, James B. Jacobs dan Kimberly Potter memahami hate crimes sebagai: ${ }^{14}$

"crimes against persons or property motivated in whole or in part by racial, ethnic, religious, gender, sexual orientation and other prejudice."

Mereka, namun demikian, mencatat adanya keberagaman definisi hate crimes yang digunakan di berbagai Negara bagian di Amerika. Terlepas dari keberagaman

\footnotetext{
11 Supra no. 8, hlm., 11.

12 Supra no. 7, hlm., 11.

13 Id.

14 Supra no 6, hlm., 366.
} 
itu, mereka menyatakan bahwa secara umum hate crimes mengandung pengertian yang sama, yakni: 15

"berbagai jenis kejahatan yang dilakukan terhadap orang atau harta bendanya yang dilatarbelakangi sebagian atau seluruhnya oleh sikap bias atau prasangka (prejudice) terhadap ras, etnis, agama, jenis kelamin dan orientasi seksual tertentu."

Sementara itu, Craig yang juga menekankan pentingnya pandangan pelaku terhadap identitas korban sebagai anggota kelompok yang dibenci, secara lebih ringkas, mengemukakan bahwa hate crimes meliputi: 16

"Illegal acts involving intentional selection of victims based on perpetrator's bias or prejudice against the actual or perceived status of the victim".

Craig, selanjutnya, menjelaskan bahwa pemilihan korban dalam hate crimes didasarkan pada sikap bias atau prejudice pelaku terhadap status atau karakter personal korban. Status atau karakter personal di sini dimaknai sebagai keanggotaan korban dalam kelompok tertentu yang dibenci oleh pelaku. Sedangkan Mason, beranjak dari pemahamannya terhadap hate crimes sebagai prejudice-related crime, mendefiniskan hate crimes sebagai 17

"Crimes, wholly or partly motivated by, grounded in, or aggravated by, bias or prejudice towards particular groups of people."

Dari sudut pandang berbeda, Barbara Perry, mendefinisikan hate crimes sebagai: 18

"A mechanism of power intended to sustain somewhat precarious hierarchies, through violence and threats of violence (verbal or physical). It is generally directed towards those whom our society has traditionally stigmatized and marginalized."

Dengan itu, Perry mengemukakan kaitan antara upaya mempertahankan hierarkhi sosial politik (posisi dominan yang dinikmati mayoritas) dengan

15 Id.

${ }^{16}$ Ryan D King, Hate Crimes: Perspectives on Offending and the Law dalam Marvin D. Krohn et al (eds), Handbook on Crime and Deviance, Springer, New York, 2012, hlm., 526-544.

17 Gail Mason, "Hate Crime Laws in Australia: Are they achieving their goals?," Sentencing Conference 2010, Canberra 6\&7 Februari 2010, hlm., 2.

18 Barbara Perry, In the Name of Hate: Understanding Hate Crimes, Routledge, New York, 2001, hlm., 3. 
kebencian dalam hate crimes. Lebih jauh, Perry memberi tekanan pada kenyataan bahwa kekerasan dan perilaku intimidatif memiliki dampak yang berbeda ketika dilatarbelakangi oleh sikap bias atau prejudice terhadap kelompok yang terpinggirkan (marginal) dan, sekaligus, bertujuan untuk menegaskan atau mempertajam perbedaan kedudukan sosial dan politik di masyarakat.

Senada dengan itu, Wolfe dan Copeland, mendefinisikan hate crimes dengan mengaitkannya pada kebijakan politik yang diskriminatif terutama terhadap kelompok-kelompok terpinggirkan. Mereka mengartikan hate crimes sebagai: 19

"Violence directed towards groups of people who generally are not valued by the majority, who suffer discrimination in other arenas, and who do not have full access to remedy social, political and economic injustice."

Korban, dalam pandangan mereka, adalah kelompok yang dalam tatanan masyarakat tertentu (mayoritas atau dominan) berada dalam posisi terpinggirkan dan sebab itu secara berkelanjutan mengalami perlakuan diskriminatif.

Selanjutnya, Sheffiled menunjukkan bagaimana hate crimes kemudian memperkuat atau melanggengkan proses peminggiran dalam masyarakat. Ia menyatakan bahwa: ${ }^{20}$

"Hate violence is motivated by social and political factors and is bolstered by belief system which (attempt to) legitimate such violence... It reveals that the personal is political; that such violence is not a series of isolated incidents but rather the consequence of a political culture which allocates rights, privileges and prestige according to biological or social characteristic."

Dengan merujuk pada pandangan Wolfe dan Copeland, serta juga Sheffield di atas, Perry menjelaskan bahwa hate crimes: ${ }^{21}$

"Involve acts of violence and intimidation, usually directed towards already stigmatized and marginalized groups. As such, it is a mechanism of power and oppression, intended to reaffirm the precarious hierarchies that characterize a given social order. It

\footnotetext{
19 Id., hlm., 9.

${ }^{20}$ Id., hlm., 9-10.
} 
attempts to recreate simultaneously the threatened (real or imagined) hegemony of the perpetrator's group and the appropriate subordinate identity of the victim's group. It is a means of marking both the Self and the Other in such a way as to re-establish their proper relative positions, as given and reproduced by broader ideologies and pattern of social and political inequality."

Dalam rumusan di atas titik tolaknya bukan kebencian semata-mata, namun tujuan kelompok dominan (mayoritas atau elit) untuk mempertahankan status sosial-politik terhadap ancaman yang dianggap muncul dari keberadaan kelompok lain (korban). Kejahatan merupakan upaya menegaskan superioritas dan keunggulan kelompok (pelaku) atas kelompok lain (yang direpresentasikan oleh korban). Maka, kejahatan kebencian dapat dipandang sebagai mechanism of power and oppression. Adalah kelompok dominan yang melalui hate crimes menegaskan dan berupaya mempertahankan keberkuasaan mereka dan secara berkelanjutan melanggengkan peminggiran kelompok minoritas (mereka yang dianggap berbeda) yang dianggap sebagai ancaman.

Dari berbagai definisi hate crimes yang ada, dapat disimpulkan bahwa kebencian atau prejudice dapat dipandang merupakan mens rea (mental element) dalam tindak pidana atau kejahatan yang diperbuat. Dengan demikian, adanya mens rea ini harus sekaligus dibuktikan dalam persidangan pidana. Kesimpulan ini, namun demikian, harus diujikan lebih lanjut. Pada bagian berikut akan dipaparkan bagaimana hate crimes diatur dalam ketentuan pidana di sejumlah negara, dan karenanya sekaligus akan tampak mekanisme pembuktiannya dalam hukum pidana.

\section{Perbandingan Pengaturan Hate Crimes dalam Hukum Pidana di Beberapa Negara}

Hate Crimes dipandang sebagai kejahatan serius yang memiliki tingkat ketercelaan berbeda dengan kejahatan pada umumnya. Karenanya dengan menggunakan pendekatan proporsionalitas (just desert principles) dipandang perlu ada dan diberikannya reaksi pidana yang berbeda dibandingkan dengan 
reaksi pidana terhadap kejahatan pada umumnya. ${ }^{22}$ Ini juga tampak dari meningkatnya angka dan berkembangnya pengaturan hate crimes melalui hukum pidana di berbagai negara. ${ }^{23}$ Sejumlah argumentasi yang mendukung penanganan hate crimes melalui hukum pidana secara khusus di berbagai Negara pada umumnya didasarkan pada pertimbangan: retribution, deterrence dan symbolic effect. $^{24}$

Berdasarkan pertimbangan retribution, maka hate crimes yang tingkat ketercelaannya dipandang lebih tinggi daripada kejahatan pada umumnya, dipandang layak diancam dengan pidana yang berbeda (sebagai delik khusus) atau dengan ancaman sanksi pidana yang lebih berat. ${ }^{25}$ Selain itu alasan terpenting untuk memunculkan reaksi pidana khusus adalah pertimbangan korban hate crimes lebih menderita secara psikologis dan emosional dibandingkan korban kejahatan lainnya yang tidak didasari motif kebencian. ${ }^{26}$ Hate crimes juga menimbulkan konflik yang berkepanjangan dalam masyarakat. Kejahatan ini berdampak buruk bukan saja pada korban, melainkan juga pada anggota kelompok lainnya (yang tidak menjadi korban langsung). Hate crimes, selain itu, dapat pula memicu reaksi balik dari kelompok yang tertindas berupa pembalasan atas dasar kesetiaan primordial dan, dengan demikian, melestarikan bibit konflik dalam masyarakat. ${ }^{27}$

Selain itu, kriminalisasi hate crimes dianggap perlu juga dalam rangka memberikan deterrent effect bagi masyarakat. ${ }^{28}$ Sama halnya dengan argumentasi kriminalisasi perbuatan lainnya, dengan diaturnya hate crimes sebagai tindak

22 Baca, antara lain, Kevin M. Carlsmith \& John M. Darley, Why Do We Punish? Deterrence and Just Deserts as Motives for Punishment, Vol. 83, No. 2, Journal of Personality and Social Psychology, 2002, hlm., 284-299. Disebutkan bahwa just desert rationale: a person deserves punishment proportionate to the moral wrong committed. A competing jurisdiction is the deterrence rationale: Punishing an offender reduces the frequency and likelihood of future offences.

${ }^{23}$ Eric Bleich, The Rise of Hate Speech and Hate Crime Laws in Libetal Democracies, Vol 37 No 6, July, Journal of Ethnic and Migration Studies, 2011, hlm., 917-934 .

${ }^{24}$ Supra no. 7, hlm., 18.

${ }^{25}$ Adams D, Punishing Hate and Achieving Equality, Winter/Spring, Criminal Justice Ethics, 2005, hlm., 20-21.

${ }^{26}$ Supra no 7, hlm., 22.

${ }^{27}$ Id., hlm., 23.

28 Id., hlm., 24. 
pidana yang diancam dengan pidana yang berat diharapkan niat pelaku potensial untuk melakukan kejahatan dapat dicegah.

Argumentasi berikutnya untuk mengancam dengan sanksi pidana perbuatan-perbuatan di atas berkenaan dengan efek simbolik kriminalisasi hate crimes. Keputusan politik untuk mengkriminalisasi suatu perbuatan tertentu (dalam hal ini kejahatan dengan latar belakang kebencian atau prejudice) menunjukkan sikap negara (yang mencerminkan nilai moral masyarakat) yang mencela/mengutuk perbuatan dimaksud. Langkah lebih jauh, bilamana penegak hukum kemudian menegakkan ketentuan pidana (yang mengancam dengan pidana hate crimes), yakni dengan cara polisi menyidik, jaksa menuntut dan pengadilan memeriksa dan menjatuhkan putusan, maka hal ini di mata masyarakat akan menegaskan kembali klaim (dari hukum pidana) bahwa perilaku tersebut adalah perilaku tercela yang sudah sepatutnya tidak ditenggang oleh masyarakat.

Dengan kata lain, ada cukup alasan untuk mengkriminalisasi hate crimes dalam hukum pidana, baik berdasarkan alasan retribution, deterrence (umum \& khusus) maupun simbolik. Dengan cara inipun, menurut hemat penulis, negara dapat mewujudkan tujuannya melindungi segenap warga negara sama di hadapan hukum dan pemerintahan.

Pada bagian berikutnya akan ditelaah pengaturan hate crimes di sejumlah negara yang serupa Indonesia juga menghadapi permasalahan hate crimes. Titik tolak pemilihan negara-negara tersebut sebagai perbandingan adalah adanya kesamaan penting dengan Indonesia, yakni negara-negara tersebut merupakan negara dengan masyarakat pluralis dari sudut pandang ras, etnis dan agama. Alasan lain adalah keterwakilan negara dari tradisi hukum common law (Amerika, Australia, Selandia Baru), civil law (Jerman, Belanda, Perancis) maupun yang campuran (Norwegia).

\section{Pengaturan Hate Crimes dalam Hukum Amerika}

Ketentuan tentang Hate crimes dalam hukum federal Amerika ditemukan tersebar di sejumlah perundang-undangan, antara lain: 42 U.S.C. section 3631 
mengenai Criminal Interference with Right to Fair Housing; 18 U.S.C. section 249 tentang Hate Crime Acts; 18 U.S.C. section 247 tentang Damage to Religious Property, Obstruction of Persons in the Free Exercise Religious Beliefs; 18 U.S.C. section 245 mengenai Federally Protected Activites; dan 28 U.S.C. section 534 mengenai Hate Crime Statistics Act.

Dalam 18 U.S.C. sec. 249 tentang Hate Crime Acts, hate crimes ${ }^{29}$ dirumuskan sebagai tindak pidana yang berdiri sendiri (substantive offence) dengan ancaman sanksi pidana tertentu. Dalam ketentuan ini, kejahatan-kejahatan yang diatur meliputi perbuatan-perbuatan: dengan sengaja menyebabkan luka pada tubuh baik menggunakan api, senjata api, senjata berbahaya lainnya, atau alat-alat peledak termasuk percobaan untuk melakukan kejahatan-kejahatan tersebut; penculikan, kekerasan/penyalahgunaan seksual yang diperberat; termasuk percobaan untuk melakukan perbuatan-perbuatan tersebut; dan percobaan untuk melakukan pembunuhan. Melalui ketentuan-ketentuan di atas kelompok yang hendak dilindungi adalah kelompok yang dibedakan dari ras, warna kulit, agama, asal-usul kebangsaan, jender, orientasi seksual, identitas jender serta disabilitas.

Di samping itu, hate crimes diatur juga dalam sejumlah peraturan negara bagian sebagai tindak pidana tersendiri yang diancam dengan sanksi pidana tertentu. Berikut adalah salah satu ketentuan hukum pidana yang mengatur hate crimes di Negara bagian Massachusetts. Dalam Section 39 The General Law of Massachusetts mengenai Assault or battery for puspose of intimidation; weapons; punishment $^{30}$ diatur tindakan kekerasan atau penyerangan terhadap orang maupun barang miliknya dengan niat mengintimidasi korban sehubungan dengan ras, warna kulit, agama, asal-usul kebangsaan, orientasi seksual, identitas jender atau disabilitas korban. Dalam ketentuan ini juga diatur sejumlah pemberatan lainnya, seperti apabila kekerasan dan serangan tersebut menimbulkan luka fisik pada korban, adanya penggunaan senapan, senjata api dan lain-lain.

\footnotetext{
${ }^{29} 18$ U.S. Code $\S 249$ - Hate crime acts <https://www.law.cornell.edu/uscode/text/18/249> [26/05/2017]

30 The 190th General Court of The Commonwealth of Massachusetts <https://malegislature.gov/Laws/GeneralLaws/PartI/TitleII/Chapter22C/Section32> [26/05/2017]
} 
Dari uraian di atas jelas bahwa Amerika Serikat memandang hate crimes sebagai ancaman serius dan mengaturnya sebagai tindak pidana yang berdiri sendiri (substantive offence) di mana motif kebencian atau niatan mengintimidasi (dalam section 39 di atas) harus dibuktikan tersendiri. Sedangkan kelompok yang hendak dilindungi adalah mereka yang dianggap berbeda dalam spektrum yang sangat luas.

\section{Pengaturan Hate Crimes dalam Hukum Australia}

Pengaturan hate crimes dalam hukum di Australia dimulai pada akhir 1980 dan berkembang lagi pada awal 2000. Pada era akhir 1980 seluruh Negara bagian dan teritori (kecuali Tasmania dan Northern Teritory) menambahkan ketentuan pidana mengenai 'serious vilification' dalam Undang-Undang anti diskriminasi. Pada awal 2000 pengaturan hate crimes dilakukan melalui amandemen peraturan perundang-undangan mengenai pemidanaan, yakni berupa pemberatan pidana bagi kejahatan yang dilakukan dengan motif prejudice terhadap kelompok tertentu. ${ }^{31}$

Dalam hukum Austalia, hate crimes, diatur dalam peraturan perundangundangan di tingkat federal maupun di tingkat negara bagian. Dalam hukum federal hate crimes diatur sebagai tindak pidana yang berdiri sendiri, yakni dalam Racial Discrimination Act 1975 sec 18C dan dalam Criminal Code Act 1995 sec 80.2(5). Sedangkan di Negara bagian New South Wales (sebagai contoh) hate crimes diatur dalam Anti-Discrimination Act 1977 (NSW) sebagai tindak pidana berdiri sendiri dan dalam Crimes (Sentencing Procedure) Act 1999 sebagai pemberatan pidana. Berbagai Negara Bagian di Australia lainnya mengatur hate crimes melalui Undang-Undang maupun criminal code (kitab Undang-Undang).

Dalam Racial Discrimination Act 1975 sec 18C, diatur secara umum offences behavior because of race, colour or national or ethnic origin. Dalam ketentuan ini kejahatan-kejahatan yang diatur meliputi perbuatan di tempat umum melakukan perbuatan menyinggung, penghinaan, tindakan mempermalukan, mengintimidasi

\footnotetext{
${ }^{31}$ Gail Mason and Andrew Dyer, A Negation of Australia's Fundamental Values: Sentencing Prejudice-Motivated Crimes, Vol 36:871, Melbourne University Law Review, 2013, hlm., 875-876.
} 
orang atau kelompok orang. Melalui aturan ini kelompok yang hendak dilindungi adalah kelompok ras, warna kulit, kebangsaan, dan etnis.

Dalam Criminal Code Act 1995 s. 80.2 (5), mengenai Security of the Commonwealth, diatur perbuatan menyuruh atau mendorong suatu kelompok menggunakan kekuatan (force) atau melakukan kekerasan (violence) terhadap kelompok lain yang dibedakan berdasarkan ras, agama, nasionalitas atau pandangan politik, yang dapat mengancam perdamaian dan ketertiban Commonwealth. Sedangkan dalam Anti-Discrimination Act 1977 (NSW), hate crimes diatur secara khusus dalam section 20D, 38T, 49ZTA, 49ZXC yang mengatur offence of serious racial vilification, offence of serious transgender vilification, offences of serious homosexual vilification, offence of serious HIV/AIDS vilification. Dalam ketentuan-ketentuan di atas, diatur bentuk-bentuk penghinaan serius terhadap kelompok tertentu yang meliputi perbuatan-perbuatan yang dilakukan di muka umum: mengobarkan kebencian, melakukan penghinaan serius, memperolok-olok, termasuk mengancam melakukan serangan terhadap fisik maupun kebendaan serta menghasut orang lain agar melakukan pengancaman untuk melakukan serangan terhadap fisik maupun kebendaan kelompok tertentu. Dalam ketentuan di atas, kelompok yang hendak dilindungi adalah kelompok ras tertentu, transgender, homoseksual, serta pengidap HIV/AIDS.

Sedangkan dalam Crimes (Sentencing Procedure) Act 1999 section 21A tentang Aggravating, Mitigating and Other Factors in Sentencing diatur secara umum pedoman pemidanaan (pemberatan pidana) bagi hate crimes. Dalam ketentuan itu pemberatan pidana diancamkan bagi kejahatan-kejahatan yang dilakukan dengan motif kebencian pada atau prejudice terhadap kelompok agama, asal-usul ras atau etnis, bahasa, orientasi seksual atau usia tertentu, atau karena memiliki disabilitas tertentu.

Berbeda dengan Amerika Serikat, di Australia hate crimes diatur baik sebagai tindak pidana berdiri sendiri maupun sebagai unsur pemberatan sanksi pidana, artinya penegak hukum memiliki pilihan yang lebih luas. Selain itu, hakim bilamana menghadapi kasus tindak pidana biasa dan kemudian menemukan adanya motif kebencian masih dapat memperberat penjatuhan pidana. 


\section{Pengaturan Hate Crimes dalam Hukum Selandia Baru}

Dalam hukum pidana Selandia Baru, hate crimes tidak diatur sebagai tindak pidana yang berdiri sendiri. Sama halnya dengan negara bagian New South Wales dan Northern Territory di Australia, pengaturan hate crimes di Selandia Baru muncul dalam bentuk pemberatan pidana (sentence aggravating factor) ${ }^{32}$ terhadap kejahatan yang dilakukan sebagai bagian atau untuk seluruhnya karena kekejaman yang ditujukan terhadap kelompok yang memiliki kesamaan karakteristik ras, warna kulit nasionalitas, agama, identitas jender (gender identity), orientasi seksual, usia atau disabilitas tertentu.

Dalam ketentuan itu juga ditegaskan bahwa kejahatan tersebut dilakukan karena korban memiliki kesamaan karakteristik dengan kelompok tertentu, dan karena pelaku menduga bahwa korban memiliki kesamaan karakteristik dengan kelompok tertentu. Kenyataan bahwa korban bukan merupakan anggota kelompok tertentu sebagaimana diduga/dipercaya oleh pelaku, tidak menghilangkan pertanggungjawaban pidana pelaku.

\section{Pengaturan Hate Crimes dalam Hukum Jerman}

Di Jerman, pengaturan mengenai hate crimes muncul dalam bentuk pemberatan sanksi pidana secara terbatas terhadap tindak pidana yang dilatarbelakangi oleh rasisme. Konsep hate crimes tidak muncul secara spesifik dalam German Criminal Code (Strafgesetzbuch-StGB). Pengaturan hate crimes, sebaliknya, muncul dalam ketentuan mengenai prinsip pemidanaan pada sec. 46 Criminal Code 1998 (di amandemen 2015). Ketentuan ini mengatur kewajiban pengadilan (hakim) untuk mempertimbangkan keadaan-keadaan yang dapat memperberat pemidanaan, antara lain, berkenaan dengan motif dan tujuan pelaku, khususnya ketika terdapat sifat rasisme atau xenophobic. Hate sebagai aggravating factor dengan demikian wajib dipertimbangkan hakim.

\footnotetext{
${ }^{32}$ Supra no 18 , hlm., 6.
} 
Hate crimes dalam penegakan hukum pidana di Jerman juga digolongkan ke dalam "politically motivated offences" (politisch motivierte kriminalität) 33 dan dirumuskan sebagai perbuatan yang dalam hal “... in the assessment of the cricumstances of the crime and/or attitude of the perpetrator, there is reason to suspect that the act was directed against a person because of his/her nationality, race, origin, ethnicity, skin color, physical appearance, sexual orientation, disability, religion or social status and the offence is thus in a causal relationship to this". Konsep ini digunakan terutama untuk kepentingan pengklasifikasian kejahatan dalam statistik kriminal.

\section{Pengaturan Hate Crimes dalam Hukum Perancis}

Dalam hukum pidana Perancis hate crimes diatur secara spesifik dalam sejumlah ketentuan di dalam France Criminal Code sebagai pemberatan sanksi secara umum terhadap kejahatan yang dilakukan karena latar belakang etnis, kebangasaan, ras dan agama serta orientasi seksual dan identitas gender korban. Dalam pasal-pasal tersebut pemberatan pidana diancamkan terhadap kejahatan maupun pelanggaran yang didahului, disertai atau diikuti dengan tulisan-tulisan atau ujaran-ujaran lisan, gambar, obyek atau tindakan dalam bentuk apapun yang merusak kehormatan atau reputasi korban. Kelompok yang hendak dilindungi oleh aturan-aturan tersebut adalah kelompok etnis, ras, kebangsaan, agama, orientasi seksual, identitas jender.

Juga diatur secara khusus sebagai pemberatan sanksi yang melekat pada masing-masing tindak pidana yakni: pembunuhan berencana, penyiksaan, pembunuhan, kekerasan, pengancaman, perkosaan, kekerasan seksual lainnya, pencurian, perusakan barang milik orang lain dan lain-lain, apabila dilakukan karena latar belakang etnis, kebangsaan, ras, atau agama, serta orientasi seksual dan identitas jender korban.

\footnotetext{
${ }^{33}$ Alke Glet, The German Hate Crime Concept: An Account of the Classification and Registration of Bias-Motivated Offences and the Implementation of the Hate Crime Model into Germany's Law Enforcement System, Internet Journal of Criminology, 2009, hlm., 4-5.
} 


\section{Pengaturan Hate Crimes dalam Hukum Belanda}

Kitab Undang-Undang Hukum Pidana Belanda (Wetboek van Strafrecht/Sr.) tidak secara khusus mengatur tentang hate crimes. Hate crimes di Belanda lebih dikenal dengan istilah "criminal discrimination". ${ }^{34}$ Dalam KUHP Belanda (Criminal Code 1881; di amandemen 2007), diatur perbuatan penghasutan untuk melakukan hate crimes yang diatur di bawah bab $\mathrm{V}$ mengenai "serious offences against public order". Pasal 137 c KUHP Belanda mengatur tentang penghinaan (insulting statement) terhadap kelompok orang atas dasar ras, agama atau kepercayaan, jender, orientasi heteroseksual atau homoseksual, atau disabilitas fisik, psikologis atau mental.

Selanjutnya ketentuan Pasal 137d mengatur perbuatan di muka umum baik secara lisan ataupun melalui tulisan ataupun gambar melakukan penghasutan (incitement) untuk membenci dan mendiskriminasi orang, atau untuk melakukan kekerasan terhadap orang atau barang miliknya. Kelompok yang dilindungi oleh aturan ini meliputi kelompok ras, agama atau kepercayaan, jender, orientasi heteroseksual atau homoseksual, atau disabilitas fisik, psikologis atau mental. Kiranya ini yang di Indonesia kemudian lebih dikenal sebagai ujaran kebencian.

Meskipun dalam KUHP Belanda tidak ditemukan pengaturan hate crimes secara khusus, Pemerintah Belanda mengeluarkan panduan bagi penyidikan, penuntutan dan penjatuhan pidana bagi kejahatan-kejahatan yang melibatkan tindakan diskriminatif, yakni Procurators General Discrimination Directives (Aanwijzing Discriminatie). Melalui pedoman ini, penuntut umum (bukan hakim seperti di Jerman) diwajibkan untuk memperberat tuntutan pidana atas kejahatan-kejahatan yang dilakukan dengan motif diskriminasi.

\section{Pengaturan Hate Crimes dalam Hukum Norwegia}

Di Norwegia aturan mengenai hate crimes muncul dalam Criminal Code 1902 (diamandemen 1994) dalam bentuk ketentuan tentang ekspresi

\footnotetext{
${ }^{34}$ Irene Sagel Grande, "Monitoring Hate Crime and Some Comparative Law Annotations”, artikel tidak dipublikasi, hlm. 13.<http://www.cep-probation.org/uploaded_files/ Monitoring\%20 Hate\%20Crime.pdf $>[26 / 05 / 2017]$
} 
diskriminatif (ungkapan perilaku yang dilandaskan diskriminasi) atau kebencian terhadap kelompok tertentu serta pemberatan ancaman pidana terhadap perbuatan penyerangan dan vandalisme yang dilakukan terhadap kelompok tertentu. Ketentuan-ketentuan tersebut pada dasarnya dibuat untuk melindungi warga negara (individu) terhadap tindakan-tindakan yang intimidatif, pelecehan serta perilaku yang seenaknya (inconsiderate behavior). ${ }^{35}$

Kelompok yang dilindungi melalui ketentuan pidana ini adalah kelompok yang dibedakan berdasarkan warna kulit, asal-usul kebangsaan dan etnis, agama, kepercayaan, orientasi homoseksual atau disabilitas.

\section{Persamaan-perbedaan Pengaturan Hate Crimes beberapa Negara}

Menurut penulis apa yang dapat dipelajari dari perbandingan pengaturan tentang hate crimes di sejumlah negara di atas adalah bagaimana negara-negara tersebut melalui hukum pidana mengatur, pertama, cakupan atau ruang lingkup pengertian hate crimes, dan kedua, bagaimana negara-negara tersebut mengembangkan model pengaturan dalam hukum pidana yang berbeda-beda serta alasan mengapa model tertentu dipilih. Secara singkat, perbandingan pengaturan hate crimes sejumlah negara sebagaimana dipaparkan di atas dapat dilihat dalam tabel berikut:

\section{Tabel 1.}

\section{Perbandingan Pengaturan Hate Crimes di Beberapa Negara}

\begin{tabular}{cllll}
\hline Negara & \multicolumn{1}{c}{ Peraturan } & \multicolumn{1}{c}{ Tindak Pidana } & $\begin{array}{c}\text { Kelompok } \\
\text { yang } \\
\text { Dilindungi }\end{array}$ & $\begin{array}{c}\text { Model } \\
\text { Pengatur- } \\
\text { an }\end{array}$ \\
\hline Amerika & 18 U.S.C. Hate & dengan sengaja menyebab- & ras, warna & kejahatan \\
& Crime Acts & kan luka pada tubuh, meng- & kulit, agama & yang \\
& Sec. 249 & gunakan api, senjata api, & atau asal-usul & berdiri \\
& senjata berbahaya, alat pe- & kebangsaan & sendiri \\
& ledak yang menyebabkan & & \\
& kematian, atau kejahatan & & \\
& melibatkan penculikan atau & & \\
& percobaan penculikan, pe- & & \\
& nyalahgunaan/kekerasan & \\
& seksual yang diperberat atau & \\
& percobaan untuk melakukan & \\
& itu & \\
& &
\end{tabular}

\footnotetext{
${ }^{35}$ Sindre Bangstad, Islamophobia in Norway: National Report 2015, hlm., 410, dalam Enes Bayrakli dan Harid Hafez (eds), European Islamophobia Report 2015, (SETA, Istanbul, 2016)
} 


\begin{tabular}{|c|c|c|c|c|}
\hline & & $\begin{array}{l}\text { dengan sengaja } \\
\text { menyebabkan luka pada } \\
\text { tubuh, menggunakan api, } \\
\text { senjata api, senjata } \\
\text { berbahaya, alat peledak atau } \\
\text { percobaan untuk itu }\end{array}$ & $\begin{array}{l}\text { agama, asal- } \\
\text { usul } \\
\text { kebangsaan, } \\
\text { jender, } \\
\text { orientasi } \\
\text { seksual, } \\
\text { identitas } \\
\text { jender, } \\
\text { disabilitas } \\
\end{array}$ & $\begin{array}{l}\text { kejahatan } \\
\text { yang } \\
\text { berdiri } \\
\text { sendiri }\end{array}$ \\
\hline & $\begin{array}{l}\text { The General Law } \\
\text { of Massachusetts } \\
\text { Sec. } 39\end{array}$ & $\begin{array}{l}\text { penyerangan atau kekerasan } \\
\text { terhadap tubuh atau barang } \\
\text { milik dengan maksud untuk } \\
\text { mengintimidasi korban }\end{array}$ & $\begin{array}{l}\text { ras, warna } \\
\text { kulit, agama, } \\
\text { asal-usul } \\
\text { kebangsaan, } \\
\text { orientasi } \\
\text { seksual, } \\
\text { identitas } \\
\text { jender, atau } \\
\text { disabilitas }\end{array}$ & $\begin{array}{l}\text { kejahatan } \\
\text { yang } \\
\text { berdiri } \\
\text { sendiri }\end{array}$ \\
\hline \multirow[t]{4}{*}{ Australia } & $\begin{array}{l}\text { Racial } \\
\text { Discrimination } \\
\text { Act } 1975 \\
\text { Sec. } 18 \mathrm{C}\end{array}$ & $\begin{array}{l}\text { di muka umum } \\
\text { menyinggung, menghina, } \\
\text { mempermalukan atau } \\
\text { mengintimidasi orang atau } \\
\text { kelompok orang }\end{array}$ & $\begin{array}{l}\text { ras, warna } \\
\text { kulit, asal- } \\
\text { usul } \\
\text { kebangsaan } \\
\text { atau etnis }\end{array}$ & $\begin{array}{l}\text { kejahatan } \\
\text { yang } \\
\text { berdiri } \\
\text { sendiri }\end{array}$ \\
\hline & $\begin{array}{l}\text { Criminal Code } \\
\text { Act } 1995 \\
\text { Sec. } 80.2(5)\end{array}$ & $\begin{array}{l}\text { mendorong orang lain untuk } \\
\text { menggunakan kekuatan atau } \\
\text { kekerasan terhadap } \\
\text { kelompok lain, dan } \\
\text { penggunaan kekuatan dan } \\
\text { kekerasan tersebut dapat } \\
\text { mengancam perdamaian, } \\
\text { ketertiban dan } \\
\text { pemerintahan yang baik }\end{array}$ & $\begin{array}{l}\text { ras, agama, } \\
\text { nasionalitas } \\
\text { atau } \\
\text { pandangan } \\
\text { politik }\end{array}$ & $\begin{array}{l}\text { kejahatan } \\
\text { yang } \\
\text { berdiri } \\
\text { sendiri }\end{array}$ \\
\hline & $\begin{array}{l}\text { Anti- } \\
\text { Discrimination } \\
\text { Act } 1977 \text { (NSW) } \\
\text { Sec. 20D, 38T, } \\
\text { 49ZTA, 49ZXC }\end{array}$ & $\begin{array}{l}\text { melakukan perbuatan di } \\
\text { muka umum berupa } \\
\text { penghasutan kebencian, } \\
\text { penghinaan serius, } \\
\text { memperolok-olok, } \\
\text { termasuk: mengancam } \\
\text { melukai fisik atau merusak } \\
\text { barang milik } \\
\text { orang/kelompok orang } \\
\text { tersebut dan menghasut } \\
\text { orang lain untuk melakukan } \\
\text { itu }\end{array}$ & $\begin{array}{l}\text { ras, } \\
\text { transjender, } \\
\text { homoseksual, } \\
\text { pengidap } \\
\text { HIV/AIDS }\end{array}$ & $\begin{array}{l}\text { kejahatan } \\
\text { yang } \\
\text { berdiri } \\
\text { sendiri }\end{array}$ \\
\hline & $\begin{array}{l}\text { Crimes } \\
\text { (Sentencing } \\
\text { Procedure) Act } \\
1999 \\
\text { Sec.21A }\end{array}$ & kejahatan umum & $\begin{array}{l}\text { agama, asal- } \\
\text { usul ras atau } \\
\text { etnisitas, } \\
\text { bahasa, } \\
\text { orientasi } \\
\text { seksual, usia, } \\
\text { disabilitas } \\
\end{array}$ & $\begin{array}{l}\text { pemberat } \\
\text { an umum }\end{array}$ \\
\hline $\begin{array}{l}\text { Selandia } \\
\text { Baru }\end{array}$ & $\begin{array}{l}\text { Sentencing Act } \\
2002(\mathrm{NZ}) \\
\text { Sec. } 9(1)(\mathrm{h})\end{array}$ & $\begin{array}{l}\text { kejahatan (umum) yang } \\
\text { sebagian atau seluruhnya } \\
\text { dilakukan karena kekejaman }\end{array}$ & $\begin{array}{l}\text { ras, } \\
\text { kebangsaan, } \\
\text { agama, }\end{array}$ & $\begin{array}{l}\text { pemberat } \\
\text { an umum }\end{array}$ \\
\hline
\end{tabular}




\begin{tabular}{|c|c|c|c|c|}
\hline & & terhadap kelompok & $\begin{array}{l}\text { identitas } \\
\text { jender, } \\
\text { orientasi } \\
\text { seksual, } \\
\text { umur, } \\
\text { disabilitas }\end{array}$ & \\
\hline Jerman & $\begin{array}{l}\text { Criminal Code } \\
\text { (StGB) } 1998 \\
\text { Sec. } 46\end{array}$ & kejahatan (umum) & Ras & $\begin{array}{l}\text { pemberat } \\
\text { an umum }\end{array}$ \\
\hline Perancis & $\begin{array}{l}\text { France Penal } \\
\text { Code } \\
\text { Art. 132-76-77 } \\
\text { Art. 221-4 } \\
\text { Art. 222-1-2 } \\
\text { Art. 222-7-13 } \\
\text { Art. 222-17-18 } \\
\text { Art. 222-18-1 } \\
\text { Art. 222-23-24 } \\
\text { Art. 222-29-30 } \\
\text { Art. 225-17-18 } \\
\text { Art. 311-1-4 } \\
\text { Art. 312-2 } \\
\text { Art. 322-2 } \\
\text { Art. 322-6 } \\
\text { Art. 322-8 }\end{array}$ & $\begin{array}{l}\text { pelanggaran atau kejahatan } \\
\text { yang didahului, disertai, } \\
\text { diikuti oleh tulisan, ucapan, } \\
\text { gambar, obyek atau tindakan } \\
\text { yang menjatuhkan harga } \\
\text { diri, reputasi } \\
\text { korban/kelompok korban } \\
\text { pembunuhan, penyiksaan, } \\
\text { kekerasan yang } \\
\text { mengakibatkan kematian, } \\
\text { kekerasan yang } \\
\text { mengakibatkan luka berat } \\
\text { atau cacat permanen, } \\
\text { kekerasan yang } \\
\text { mengakibatkan } \\
\text { ketidakmampuan untuk } \\
\text { bekerja, perkosaan, } \\
\text { kekerasan seksual selain } \\
\text { perkosaan, penghancuran } \\
\text { atau perusakan barang, dll. }\end{array}$ & $\begin{array}{l}\text { etnis, } \\
\text { kebangsaan, } \\
\text { ras, agama, } \\
\text { orientasi } \\
\text { seksual atau } \\
\text { identitas } \\
\text { jender }\end{array}$ & $\begin{array}{l}\text { pemberat } \\
\text { an pasal- } \\
\text { pasal } \\
\text { tertentu }\end{array}$ \\
\hline \multirow[t]{2}{*}{ Belanda } & $\begin{array}{l}\text { Criminal Code } \\
1881 \\
\text { Art. } 137 \mathrm{~d}\end{array}$ & $\begin{array}{l}\text { Di muka umum secara lisan, } \\
\text { tulisan atau melalui gambar, } \\
\text { menghasut kebencian atau } \\
\text { diskriminasi, melakukan } \\
\text { kekerasan terhadap orang } \\
\text { atau barang miliknya }\end{array}$ & $\begin{array}{l}\text { ras, agama } \\
\text { atau } \\
\text { keyakinan, } \\
\text { jender, } \\
\text { orientasi } \\
\text { heteroseksual } \\
\text { atau } \\
\text { homoseksual, } \\
\text { kondisi fisik } \\
\text { psikologis } \\
\text { atau mental }\end{array}$ & $\begin{array}{l}\text { kejahatan } \\
\text { yang } \\
\text { berdiri } \\
\text { sendiri }\end{array}$ \\
\hline & $\begin{array}{l}\text { Procurators } \\
\text { General } \\
\text { Discrimination } \\
\text { Directives }\end{array}$ & kejahatan (umum) & Umum & $\begin{array}{l}\text { pemberat } \\
\text { an } \\
\text { tuntutan }\end{array}$ \\
\hline Norwegia & $\begin{array}{l}\text { Ciminal Code } \\
1902 \\
\text { Sec. } 135 \mathrm{a} \\
\text { Sec. } 292\end{array}$ & $\begin{array}{l}\text { Mengekspresikan sikap } \\
\text { diskriminatif atau kebencian } \\
\text { penyerangan dan } \\
\text { vandalisme (perusakan) }\end{array}$ & $\begin{array}{l}\text { warna kulit, } \\
\text { asal-usul } \\
\text { kebangsaan } \\
\text { atau etnis, } \\
\text { agama, } \\
\text { kepercayaan, } \\
\text { orientasi } \\
\text { homoseksual, } \\
\text { atau } \\
\text { disabilitas }\end{array}$ & $\begin{array}{l}\text { Tindak } \\
\text { pidana } \\
\text { yang } \\
\text { berdiri } \\
\text { sendiri } \\
\text { dan } \\
\text { Pemberat } \\
\text { an }\end{array}$ \\
\hline
\end{tabular}


Dilihat dari ruang lingkup pengertian yang diberikan tiap negara tampak sejumlah persamaan dan perbedaan dalam pengaturan hate crimes dalam hukum di beberapa negara di atas. Persamaan yang tampak dari pengaturan hate crimes di negara-negara di atas adalah fokusnya pada kelompok (rentan-minoritas) yang dilindungi. Meskipun terdapat sedikit variasi, dapat dilihat bahwa kelompokkelompok yang hendak dilindungi adalah kelompok minoritas dalam masyarakat.

Hampir seluruh negara di atas memasukkan unsur kelompok ras, agama, asal-usul kebangsaan, etnis, orientasi seksual, identitas gender, dan disabilitas ke dalam rumusan ketentuan yang mengatur hate crimes. Sedikit berbeda dengan pola umum ini, Australia dan Selandia Baru memasukkan kriteria 'usia' ke dalam kelompok yang hendak dilindungi. Lebih jauh, Australia menambahkan dan memasukkan kelompok 'pengidap HIV/AIDS' sebagai kelompok yang dilindungi dalam ketentuan hate crimes. Perbedaan-perbedaan dalam penentuan ruang lingkup atau cakupan kelompok yang hendak dilindungi ini kiranya sangat erat dengan situasi sosial-politik dan pengalaman masing-masing Negara yang berbeda-beda dalam menghadapi tantangan keberagaman masyarakatnya. Sekaligus juga dapat dibayangkan kelompok manakah yang dominan-mayoritas dan merasa terancam oleh kehadiran kelompok minoritas. Singkat kata, konteks sosial politik masyarakat negara menentukan ruang lingkup perlindungan yang diberikan.

Perbedaan yang lebih jelas tampak dalam hal pengaturan kejahatan atau perbuatan yang dijadikan unsur dalam hate crimes. Amerika dalam 18 U.S.C. Hate Crime Acts maupun dalam The General Law of Massachusetts mengatur perbuatan penyerangan atau kekerasan terhadap tubuh dan barang (harta milik); Australia merujuk pada perbuatan penghinaan, intimidasi, mendorong orang lain untuk melakukan kekerasan, penghasutan maupun kejahatan pada umumnya; Selandia Baru dan Jerman memasukkan kejahatan pada umumnya; Perancis memasukkan baik kejahatan secara umum maupun kejahatan-kejahatan tertentu seperti pembunuhan, penyiksaan, kekerasan, perkosaan dan lain-lain; Belanda melalui KUHP-nya hanya memasukkan perbuatan penghasutan, sedangkan surat petunjuk Jaksa Agung (Aanwijzing Discriminatie/Procurators General Discrimination 
Directives) berlaku bagi kejahatan pada umumnya; sedangkan Norwegia memasukkan kejahatan kekerasan berupa ekspresi diskriminatif atau kebencian serta penyerangan dan vandalisme. Dari perbedaan-perbedaan ini tampak bagaimana tiap negara secara simbolik mencela spektrum perbuatan yang berbeda-beda serta juga dalam tingkatan berbeda-beda, sekalipun tetap hanya perbuatan yang dilatarbelakangi kebencian atau prejudice. Pilihan perbuatan yang dikaitkan dengan hate crimes kiranya juga berkaitan dengan kejahatan-kejahatan nyata seperti apa yang paling sering muncul di negara-negara tersebut.

Selanjutnya, dari sudut pandang model pengaturannya, secara umum, tampak bahwa hate crimes diatur dalam dua model pengaturan yakni: pertama, secara khusus diatur sebagai tindak pidana tersendiri dengan ancaman pidana tertentu (substantive offences) yang memasukkan elemen "latar belakang/motif kebencian" sebagai unsur integral dari tindak pidana. Kedua, hate crimes diatur sebagai pemberatan pidana tanpa membuat rumusan tersendiri tentang itu. Pengaturan sebagai pemberatan pidana inipun dapat dibagi lagi menjadi dua model, yakni yang melekat dalam masing-masing tindak pidana (tertentu), dan yang kedua diatur secara umum dalam ketentuan mengenai pemidanaan sebagai pemberatan ancaman pidana.

Pengaturan atau perumusan hate crimes sebagai tindak pidana yang berdiri sendiri akan dengan jelas menunjukan sikap negara (symbolic effect) bahwa negara tidak akan menenggang hate crimes. Pesan simbolik ini ditujukan pada calon pelaku (dari kelompok dominan) sebagai deterence (fungsi prevensi umum) maupun pada kelompok minoritas, yakni bahwa Negara akan melindungi mereka. Pada saat sama, metoda ini membawa implikasi bahwa pelaku hanya dapat dihukum manakala semua unsur dinyatakan terbukti. Kegagalan penutut umum dalam membuktikan adanya mens rea berupa "latar belakang kebencian/prejudice/sikap bias" akan berdampak pada tidak terbuktinya kejahatan secara keseluruhan. Artinya, pelaku akan bebas dari jeratan pertanggungjawaban pidana, sementara korban sudah mengalami diskriminasi atau kejahatan lain. 
Sedangkan, pengaturan hate crimes sebagai pemberatan pidana, meskipun di satu sisi tidak memiliki symbolic effect yang cukup penting, namun berisiko lebih kecil dalam kegagalan menghukum pelaku. Keuntungannya ialah bahwa bagi hakim terbuka pilihan untuk bilamana dalam persidangan terbukti bahwa kejahatan yang sedang diperiksa ternyata berlatarbelakang kebencian atau prejudice menjatuhkan pidana yang lebih berat, artinya terbuka peluang untuk menjatuhkan pidana yang proporsional dengan kejahatan yang dilakukan dan artinya lebih memenuhi rasa keadilan.

\section{Pengaturan Hate Crimes dalam Hukum Pidana di Indonesia}

Seperti telah disebutkan bagian pendahuluan Indonesia mengenal pengaturan hate speech dalam Undang-Undang Informasi dan Transaksi Elektronik (Undang-Undang No. 11 tahun 2008). Namun ini jelas tidak sama dan sebangun dengan hate crimes yang mencakup hampir semua kejahatan yang dilakukan berdasarkan atau bermotifkan kebencian atau prejudice sebagaimana dibahas dalam tulisan ini. Dalam hukum pidana Indonesia, ketentuan khusus yang mengatur hate crimes (kriminalisasi hate crimes) hanya muncul di dalam Pasal $4 \mathrm{~b}$ (4) Undang-Undang 40 Tahun 2008 tentang Penghapusan Diskriminasi Ras dan Etnis atas kejahatan-kejahatan tertentu yakni:

“...melakukan perampasan nyawa orang lain, penganiayaan, perkosaan, perbuatan cabul, pencurian dengan kekerasan atau perampasan kemerdekaan berdasarkan diskriminasi ras dan etnis."

Rumusan di atas dibandingkan dengan spektrum luas yang muncul dari pengaturan hate crimes Negara-negara lain, ternyata hanya ditujukan pada (kejahatan yang dilakukan atas dasar adanya) diskriminasi ras dan etnis. Tidak diperhitungkan perilaku diskriminatif (hate crimes) yang dilandaskan perbedaan agama/keyakinan (yang dalam masyarakat Indonesia merupakan bagian dari identitas paling penting). Juga diabaikan diskriminasi berdasarkan kriterium lainnya yang juga menjadi sangat penting, misalnya jender, asal-usul, kelompok LGBT, dll. Kekurangan ini kiranya terjadi karena Undang-Undang 40 Tahun 2008 diterbitkan untuk memenuhi kewajiban Indonesia di bawah hukum internasional 
atau khususnya dalam rangka implementasi International Convention on the Elimination of All Forms of Racial Discrimination 1965 yang diratifikasi pemerintah Indonesia pada 1999.

Selain itu, dengan mengikuti rumusan di atas, kejahatan-kejahatan umum (perampasan nyawa, perkosaan, pencurian dan lain-lain) harus dilakukan berdasarkan (dengan adanya motif) diskriminasi ras dan etnis. Artinya penuntut umum, bilamana menggunakan ketentuan ini harus membuktikan unsur: berdasarkan diskriminasi ras dan etnis. Risikonya adalah kegagalan membuktikan adanya unsur ini dan kemudian pelaku bebas atau lepas.

Seperti telah disinggung di atas, tidak ditemukan pengaturan khusus tentang hate crimes yang dilatarbelakangi oleh sikap prejudice atau kebencian terhadap kelompok agama. Sementara, merujuk pada banyak kasus hate crimes yang terjadi di Indonesia (Syiah di Sampang-Madura; Syiah di Cikeusik-Jawa Barat; perang agama Ambon-Maluku, dll), kekerasan yang dilakukan kelompok dominan lebih banyak dilatarbelakangi oleh sikap prejudice atau kebencian terhadap kelompok agama lain (minoritas yang berbeda dan dianggap sebagai gangguan bahkan ancaman).

Kekurangan-kekurangan dalam hukum pidana Indonesia inilah yang harus ditanggapi oleh pemerintah. Kejahatan yang berbasis diskriminasi, kebencian dan prejudice nyata ada dan mengancam keutuhan (persatuan-kesatuan) masyarakat Indonesia yang dicirikan kebhinekaan. Negara melalui pembuat undang-undang nyata harus menentukan sikap terhadap hate crimes yang terjadi di Indonesia. Pilihan yang tersedia, dengan bercermin pada ragam pola pengaturan dari berbagai negara, adalah merumuskannya sebagai tindak pidana yang berdiri sendiri ataupun sebagai unsur pemberatan pidana.

\section{Penutup}

Di Indonesia kebencian atau prejudice yang dimanifestasikan dalam berbagai bentuk perlakuan diskriminatif, dengan maupun tanpa kekerasan, tidak atau belum mendapat reaksi yang memadai dari negara melalui aparat penegak hukumnya, sehingga kerap terkesan terjadi pembiaran oleh negara. Apalagi untuk 
sejumlah kasus yang terjadi bukan lagi pembiaran, melainkan negara memberikan legitimasi bagi masyarakat, melalui hukum maupun kebijakan lainnya, untuk "membenci" dan melakukan berbagai bentuk kekerasan (state-sponsored collective violence).

Dari sudut pandang di atas, maka ternyata hukum pidana Indonesia tidak cukup memadai untuk meminta pertanggungjawaban para pelaku kejahatankejahatan sebagaimana dipaparkan di atas. Ini dikatakan juga dengan melihat bagaimana hate crimes di sejumlah negara telah diatur melalui hukum pidana baik sebagai kejahatan yang berdiri sendiri, maupun sebagai pemberatan sanksi pidana. Dengan menggunakan berbagai model pengaturan, hate crimes di negaranegara tersebut ternyata dipandang layak mendapat ancaman pidana lebih berat, yaitu dengan mempertimbangkan adanya efek negatif yang jauh lebih besar dibandingkan dengan kejahatan pada umumnya.

\section{Daftar Pustaka}

\section{Buku:}

Adams D, Punishing Hate and Achieving Equality, Winter/Spring, Criminal Justice Ethics, 2005.

Bangstad S, Islamophobia in Norway: National Report 2015, dalam Enes Bayrakli dan Harid Hafez (eds), European Islamophobia Report 2015, SETA, Istanbul, 2016.

Chakraborti N and Garland J, Hate Crime: Impact, Causes and Responses, Sage Publications, London, 2009.

Gerstenfeld P B., Hate Crimes, Causes, Controls and Controversies, $3^{\text {rd }}$ ed, Sage Publications, California, 2013.

Grande I S, Hate Crime, Comparative Law Annotation, Groningen University, 2006. Jacobs J B. and Potter K, Hate Crimes: Criminal Law \& Identity Politics, Oxford University Press, Oxford, 1998.

King R D, Hate Crimes: Perspectives on Offending and the Law dalam Marvin D. Krohn et al (eds), Handbook on Crime and Deviance, Springer, New York, 2012.

Perry B, In the Name of Hate: Understanding Hate Crimes, Routledge, New York, 2001.

\section{Jurnal:}

Bleich E, The Rise of Hate Speech and Hate Crime Laws in Libetal Democracies, Vol 37 No. 6, July, Journal of Ethnic and Migration Studies, 2011. 
Carlsmith K M. and Darley J M., Why Do We Punish? Deterrence and Just Deserts as Motives for Punishment, Vol. 83, No. 2, Journal of Personality and Social Psychology 2002.

Glet A, The German Hate Crime Concept: An Account of the Classification and Registration of Bias-Motivated Offences and the Implementation of the Hate Crime Model into Germany's Law Enforcement System, Internet Journal of Criminology, 2009.

Goodall K, Conceptualising 'Racism' in Criminal Law, Vol. 33 No 2 June, Legal Studies, 2013

Jacobs J B. dan Henry J, The Social Construction of Hate Crime Epidemic, Vol 86 No 2, The Journal of Criminal Law \& Criminology, 1996.

Mason G and Dyer A, A Negation of Australia's Fundamental Values: Sentencing Prejudice-Motivated Crimes, Vol 36:871, Melbourne University Law Review, 2013.

\section{Lain-lain:}

Ahmad Zulfikar Fazli, “25 Kasus Intoleran Terjadi di Indonesia Sepanjang 2016”, metrotvnews, 5 Januari 2017,

<http://news.metrotvnews.com/hukum/8N0YX4wb-25-kasus-intoleranterjadi-di-indonesia-sepanjang-2016>

Grande I S, "Monitoring Hate Crime and Some Comparative Law Annotations", artikel tidak dipublikasi, hlm. 13.<http://www.cepprobation.org/uploaded_files/Monitoring\%20Hate\%20Crime.pdf

Heyder Affan dan Christine Franciska, "Pengusiran 1,000 eks anggota Gafatar merupakan Pelanggaran," BBC Indonesia, 21 Januari 2016 <http://www.bbc.com/indonesia/berita_indonesia/2016/01/160120_ind onesia_pengusiran_gafatar>

Isyana Artharini, "Alasan Pembubaran Acara Natal di Bandung Mengada-Ada”, BBC Indonesia, 8 Desember 2016 <http://www.bbc.com/indonesia/indonesia-38233417>

Mason G, "Hate Crime Laws in Australia: Are they achieving their goals?," Sentencing Conference 2010, Canberra 6\&7 Februari 2010.

18 U.S. Code $\S 249$ - Hate crime acts <https://www.law.cornell.edu/uscode/text/18/249>

The 190th General Court of The Commonwealth of Massachusetts <https://malegislature.gov/Laws/GeneralLaws/PartI/TitleII/Chapter22C/ Section32>

Tanpa nama, "Kronologi Pengusiran Jemaat Ahmadiyah diBangka", TEMPO.CO, 9 Februari 2016, <https://m.tempo.co/read/news/2016/02/09/058743223/ini-kronologipengusiran-jemaat-ahmadiyah-di-bangka> 